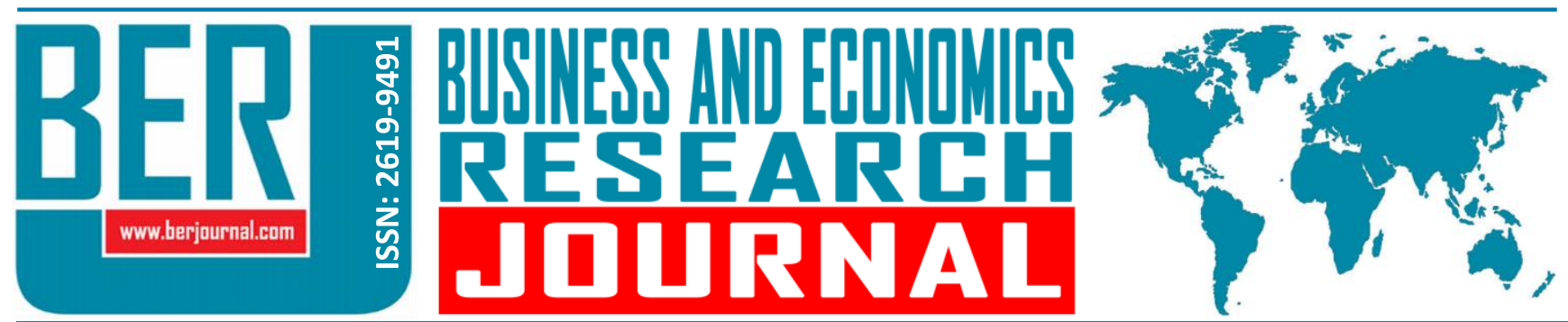

Business and Economics Research Journal Vol. 10, No. 4, 2019, pp. 845-853 doi: 10.20409/berj.2019.205

\title{
The Stock Price Behavior of Participation Index Firms: The Event Study on Borsa Istanbul
}

\author{
Yasemin Deniz Koc $^{\mathrm{a}}$, Sibel Celik ${ }^{\mathrm{b}}$, Hakan Celikkol $^{\mathrm{c}}$
}

Abstract: The index type created from the stocks of companies operating in accordance with Islamic principles is called "participation index". In this study, whether the inclusion of companies operating in Borsa Istanbul National Market and in accordance with Participation Banking principles in the BIST Participation 30 Index had an effect on the price of stocks, was analyzed with the event study method. As a result of the analysis, it was observed that the cumulative abnormal returns had been on decline before the companies were included in the participation index, and the decline continued on the day of the event and the following days. The findings obtained are meaningful and typical for all relevant economic units, especially for investors and market makers.

\author{
Keywords: Participation \\ Index, BIST Participation 30 \\ Index, Borsa Istanbul, Event \\ Study Method, Stock Prices, \\ Cumulative Abnormal Return \\ JEL: G10, G14, G21 \\ Received : 28 November 2018 \\ Revised : 24 January 2019 \\ Accepted : 17 May 2019 \\ Type : Research
}

\section{Introduction}

Islamic finance practices in Turkey started in the first established as name of private financial institution, and then continue to operate as a bank with participation banking of commercial banks since 2005 in the banking sector. Following the foundation of participation banks' market share, number of customers and profitability while a large share of the banking system also forms the basis of the Islamic financial system in Turkey. The development in financial markets has allowed the diversification of Islamic finance as different markets and instruments. This diversification is reflected by Islamic indexes and stocks under Islamic capital markets, while Islamic insurance practices, also referred to as takaful insurance applications in the insurance sector noteworthy.

Participation banks operating in accordance with the principles of Islamic banking are known to be involved in the financial system for many years. As a different aspect of this understanding; the indexes (participation indexes) established from the stocks of companies operating in accordance with Islamic principles also started to be established in stock exchanges since 1990s. Islamic indexes first started with the DMI 150 (Dar al Mal al-Islami) Index in April 1998, which was followed by the performances of the top 150 companies in the world. In the same year, SAMI (Socially Aware Muslim Index) Index was created to measure the performance of 500 companies in accordance with Sharia. (El Khamlichi et.al., 2014) Based on the

Assoc. Prof., PhD., Dumlupinar University, School of Applied Sciences, Kutahya, Turkiye, denizkoc12@gmail.com (ORCID ID: 0000-0001-8280-7657)

b Assoc. Prof., PhD., Dumlupinar University, School of Applied Sciences, Kutahya, Turkiye, sibelcelik1@gmail.com (ORCID ID : 00000003-4430-9803)

Asst. Prof., PhD., Dumlupinar University, Faculty of Economics and Administrative Sciences, Kutahya, Turkiye, hakan.celikkol@dpu.edu.tr (ORCID ID : 0000-0001-9345-1596) 
principles of participation banks; RHB Unit Trust Management of Malesia established in 1996, Dow Jones Islamic Index, FTSE Global Islamic Index, S\&P 500 Shari'a Index, S\&P European 350 Shari'a Index, S\&P Japan Shari'a Index (DIIM) and STOXX European Islamic Index established in 1996 are among the first examples of worldwide known "participation indexes" (Mannan \& Suisse, 2008: 115).

The Participation Indexes of Borsa Istanbul (Participation 50 Index, Participation 30 Index, Participation Model Portfolio Index), started to be calculated since 2011 but all publicly published on year 2014, has made a great progress since their establishment. Also, Dow Jones Islamic Market Turkey Index, which includes the companies listed in Borsa Istanbul, prepared by Dow Jones and Dow Jones Islamic Market Turkey Index, which has the same standards, has been published with DJIMTR code as of 30/09/2004 through the main data providers such as Reuters, Bloomberg. Immediately after the calculation of DJIMTR, the first stock exchange investment fund, which was affiliated to an Islamic market index (DJIMTR) for the first time in the world, was offered to the public in 2006. With DJIM Turkey A Type Exchange Traded Fund, Participation Index A type the ETF that was established in 2012 based on Participation Index is traded in the market (Yıldız, 2015).

In the study, whether the inclusion of the companies with above mentioned criteria in BIST 30 Participation Index has any effect on the price performance of stocks, was investigated with "event study method". Within this scope, the study was planned in five sections, including introduction, literature review, data and methodology, empirical findings and results, and on the day of the event and on the following days, abnormal and cumulative abnormal returns were calculated and their significancy were interpreted. This study is significant and specific in terms of showing that the studies on participation index in national literature are very limited and whether the inclusion of companies in the participation index has any effect on stock returns. In this respect, the study is expected to contribute to the literature.

\section{Participation Index}

Islamic equities refer to the shares of companies operating in areas appropriate to Sharia law, while Islamic indexes refer to the indices of these companies and their shares. The compliance of a stock with Islamic principles is determined by looking at the sectoral and balance sheet structures. According to Islam, the shares belonging to the sectors considered as haram are not included in the index, while the existence of various financial ratios and the degree of interest rate are determined by Islamic indexes. The BIST participation indices that were created in 2011 and started to be calculated in 2014 are formed according to this rule.

The companies to be included in BIST Participation 30 and BIST Participation 50 Indexes were evaluated from two aspects, including "main area of activity" and, "financial criteria":

- $\quad$ Regarding the review in respect to the main area of activity; the companies, of which areas of activity do not cover interest-driven finance, trade, services, mediate (banking, insurance, leasing, factoring and other interest-driven activities) alcoholic beverages, gambling, chance games, pork etc. foodstuffs, press, broadcast, advertising, tourism, entertainment, tobacco products, weapons, futures gold, silver and currency trade are considered as those that can be involved in participation index. Accordingly, companies, of which areas of activity are associated with above mentioned areas, and do not have a specific provision for compliance with the principles of participation banking in their principal agreements, are not involved in BIST Participation 30 and 50 Indexes.

- Regarding the review in respect to the financial criteria; the companies are required to meet below conditions ${ }^{1}$ :

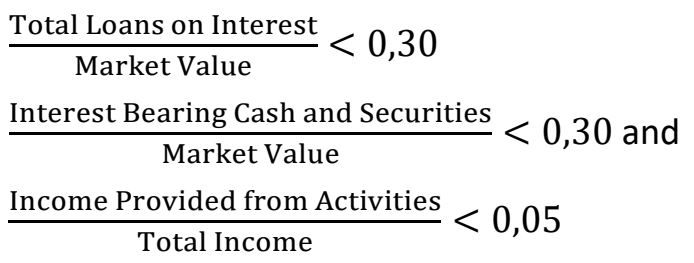


The companies ranking among first 30 and 50 companies, in respect to having public securities with highest market value, from those considered to be appropriate for Participation Banking principles in terms of area of activity and financial criteria are involved in BIST Participation 30 Index and BIST Participation 50 Index respectively; the companies that are determined to be unable to maintain these criteria are excluded from the index they are involved. The Participation Model Portfolio Index is constituted on the basis of selection made according to "credit rating methodology" among the companies included in the Participation 50 Index as of "valuation day" (www.katilimendeksi.org [Access: 20 June 2018]).

Nowadays, it is difficult to choose the stocks that are in line with the expectations of investors who want to invest in the stock pairs in accordance with the Islamic principles. In this respect, participation indices and enterprises involved in these indices will facilitate investors' portfolio diversification decisions. The findings obtained from this study will give an important information to the investors in order to show the effect of the inclusion of the enterprises in the capital markets in accordance with the Islamic principles on the stock returns.

\section{Literature}

As the history of Islamic indices is new, it is not possible to reach studies in the literature related to Islamic Indexes from different perspectives. The international literature focuses mainly on the Dow Jones Islamic Market Index, FTSE and the Kuala Lampur Shariah Index. It is seen that studies regarding Islamic indexes (participation indices), included in the international literature, are mainly focused on measuring return performance and the relationship with other indexes. As well as Atta (2000) concluded that the Dow Jones Islamic Market Index yielded superior returns, Beik and Wardhana (2011) concluded that the Jakarta Islamic Index has the least volatility and more stable compared to others in the market. Hussein and Omran (2005) found that Islamic indexes showed high performance in bull markets only, which is also supported by Hassan \& Girard's (2011) study in which they found that DJIMI indexes showed higher performance in emerging markets. As well as Hakim and Rashidian (2002) concluded that there is no long-term relationship between DJIMI and Wilshire 5000 Index for the period 1999-2002; Albaity and Ahmad, differently from this, (2008) found in their study in which they compared Kuala Lumpur Composite Index and Kuala Lumpur Sharia Index's performance that Sharia Index, even a little, has a lower performance and there is a long-term bidirectional relationship between indexes.

Some of the studies in the literature have investigated the performance of the stock indexes of the countries and the Islamic indexes especially for the crisis periods. Al-Khazali et al. (2014) found that the Islamic Indexes performed better than the normal similar stock indices during the recent global economic crisis. Shubbar (2010) found no statistically significant difference between the DJIMI Index and FTSE Shari'a All World Index's performance during the crisis period. Dharani and Natarajan (2011) found that the indices showed similar performances in the comparative study of Islamic and normal index in India. In the study, in which Abbes (2012) compared the Islamic and normal indices in 35 developed and developing countries and in the Gulf region, it was observed that there was no difference between the performance of the indices and the difference was evident in the crisis periods.

A limited number of study for participation index have been conducted in Turkey. Savaşan et al. (2015) investigated the effects of external shocks on BIST Participation 30 Index through unit root tests for the period of 2011-2015, and found that the series is not non-stationary, contains unit root and that the effects of external shocks incurred by participation index series would be permanent. The empirical results suggest that there is an exogenous shock its impact on Participation 30 Index will be permanent. While Altın and Caba (2016) found in the study in which they measured the performance of BIST Participation Index and compared it with market return that participation index yielded a better performance than market return; YIIdız (2015) investigated the risks and returns of BIST Participation 30 Index and BIST 100 Index for the period 2011-2014, and found that there was no significant difference between returns according to the $t$ test.

It is seen that event study method is used as a method of analysis in many studies done in the field of finance, especially for investigating the effects of other indexes or different events The following studies 
can be shown as examples for those where event study method is used: Sipahi (2010)'s study revealing that the rating announcements made for the period 2003-2008 didn't have a significant effect on stock returns; Sakarya (2011)'s study revealing that there was a significant relationship between that Istanbul stock exchange securities got a sufficient corporate governance rating note for the year 2009 and their returns; Gürer (2014)'s study revealing that the changes in credit ratings didn't cause a statistical change in Turkey's public securities spreads, and market players reduced the effects of rating change by taking due precautions; Yilmaz (2014)'s study revealing that the positive rating announcements made by credit rating agencies created a significant effect on and negative announcements had no effect on credit default swaps; Eyüboğlu and Bulut (2015)'s study revealing that BIST 30 trading securities were sensitive to the news related to operational, financial and restructuring issues announced by companies; Korkmaz et al. (2017) study revealing that the rise in Turkey's credit rating up to the investible level created a positive impact on returns on share in general, and returns on share increased after the date of the event, the drop in Turkey's credit rating below the investible level didn't cause a significant change in returns on share; Yıldırım (2017)'s study revealing that credit ratings given by credit rating agencies had a half effect on the indexes of six sectors included in BIST; Yazgan (2017)'s study revealing that there was no positive relationship between the announcement of corporate governance rating and stock returns; Yıldırım et al. (2018)'s study revealing that credit ratings given by credit rating agencies had a half effect on selected indexes.

In the literature, the study investigating the effect of inclusion in participation index on stock returns could not be reached with the event study method. However, it is possible to reach the studies investigating the effect of the inclusion of different indices such as corporate governance index and sustainability index on the stock returns of enterprises with event study method. In these studies, Sakarya (2011), in the study which investigated the effect of the companies which are traded on the BIST and which have a corporate governance rating in 2009, on the BIST corporate governance index through event study method, It conclused that corporate governance index has a positive effect. Kılıç (2011), in the study that 28 companies included in the BIST Corporate Governance Index are exposed to the Corporate Governance Index and immediately after the announcement of the price of the stocks, It was concluded that the companies included in the corporate governance index provided a positive return to the investor in the following days, it was concluded that the impact of inclusion of these companies in the corporate governance index decreased significantly. Yavuz et al. (2015) examines the relationship between corporate governance index and stock returns with event study method, the abnormal returns that occurred on the days before and after the receipt of the index have been mixed and have no effect. ÇItak and Ersoy (2016), in their studies on the effect of inclusion of the companies in the sustainability index on the stock returns, they found that the inclusion of the index didn't have any effect on stock returns.

As it can be seen from above mentioned studies, there are different studies on participation indexes. The event study method is frequently used in finance literature. However, neither in national nor in international literature, there is not enough study measuring the stocks' price performance oriented effect of the companies' inclusion in the participation index, by the event study method. In this respect, the study is unique and is expected to contribute to the literature.

\section{Data and Methodology}

In this study, in which the event study method has been applied; each of the dates on which companies operating in Borsa Istanbul was included in BIST Participation 30 Index was accepted as the day of the event. Whether the inclusion in the participation index had any effect on the return performance of stocks was analyzed by calculating abnormal and cumulative abnormal returns. The date information about each of 90 companies $^{21}$ inclusion in participation index was reached from participation index website, and the closing prices of stocks and BIST 100 Index values were obtained from yahoofinance [Access: 20 April 2018].

In event study methodology; an unexpected event should be selected and the exact date of the event should be determined and the data of the companies, affected from such event, before and after the event (e.g. 15 days or 30 days before the event, 15 days or 30 days after the event etc.) should be collected 
respectively. Researchers can generally use daily, weekly or monthly feedbacks, depending on how quickly information is included in prices. The abnormal rate of return is determined to assess the effect of the event. The abnormal returns based on the observations of the event window are estimated. Abnormal returns are defined as the difference between the actual returns in the event window and the normal returns in the event window (expected return in the event that event does not take place).Based on abnormal returns, a deduction is made on the effect of the event. model (1);

The change in the stock returns of the companies in the event study was calculated using market

$$
R_{i, t}=\alpha_{i}+\beta_{i} R_{m t}+\varepsilon_{i t}
$$

$R_{i, t}$, refers to the stock value of each company in the period $t, R_{m t i}$, the value of BIST100 index in period $t, \varepsilon_{i t}$, error term with a mean of zero. $\alpha_{i} v e \beta_{i}$ represent regression parameters, which were estimated by least squares regression model. Abnormal return was calculated by following equation (Mackinlay, 1997: 15);

$$
A R_{i t}=R_{i t}-\hat{\alpha}_{i}-\hat{\beta}_{i} R_{m t}
$$

After calculating the abnormal returns for each stock by (1) numbered equation, the average abnormal return $\overline{A R}_{t}$ was calculated as follows;

$$
\overline{A R}_{t}=(1 / N) \sum_{i=1}^{N} A R_{i t}
$$

$\mathrm{N}$ in the formula refers to the number of stocks in the sample, and average cumulative abnormal return $\overline{C A R}$ was calculated as below;

$$
\overline{C A R}=\sum_{l=1}^{L} \overline{A R_{l}}
$$

t statistical values were calculated to test the significance of abnormal return. The standard deviation value of the horizontal section is used in the calculation of the $t$ statistical values, which was calculated as follows;

$$
S_{t}=\sqrt{\left(\left[\frac{1}{N-1}\right] \sum_{i=1}^{N}\left[A R_{i t}-\overline{A R}_{t}\right]^{2}\right)}
$$

After the standard deviation value was calculated, the test statistic value for abnormal returns was calculated as follows (Armitage, 1995: 36);

$$
\frac{\overline{A R}_{t}}{S_{t} / \sqrt{N}}
$$

Test statistical value for cumulative abnormal returns was calculated as follows, $T$ value in the formula is the number of days for which the cumulative abnormal return, from $t_{1}$ to $t_{2}$, was calculated;

$$
\frac{\operatorname{CAR}\left(t_{1}, t_{2}\right)}{S_{t} * \sqrt{T}}
$$


In the event study, the entire sampling was divided into 3 groups, including event period, calculation period, and the post- event period. This distinction allows the calculation of the normal return parameters without being affected from the returns during the event period. When the event window is added to the calculation, then normal model parameters guide the returns during the event period (Mackinlay, 1997: 15).

\section{Stock Prices}

\section{Empirical Findings Regarding the Effect of the Inclusion of Companies in Participation Index on}

The dates of the inclusion of the companies in the participation index were regarded as the day of the event, the period in which AR and CAR calculations are made 15 days before and after the day of the event as review period, and the period 150 days before the day of the event as estimation period.

Figure 1. The Period Schedule of Event Study Regarding the Inclusion of Companies in Participation Index
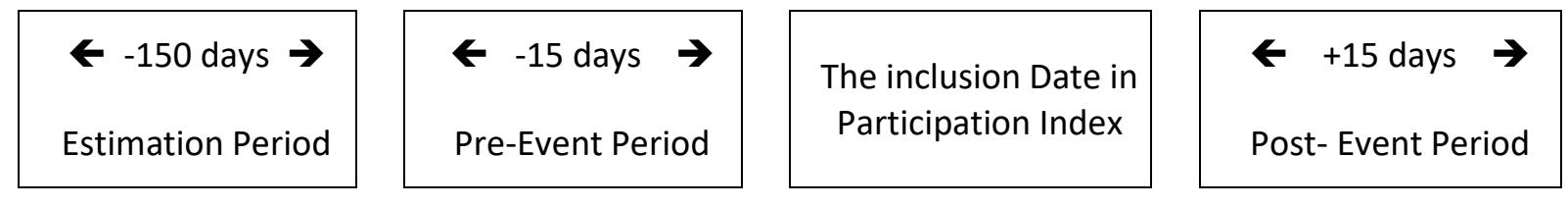

Table 1. AR and CAR Calculations for the Effect of the Inclusion of Companies in Participation Index on Stock Prices

\begin{tabular}{|c|c|c|c|c|}
\hline Days & $A R$ & t statistics (AR) & CAR & t statistics (CAR) \\
\hline-15 & -0.01285 & $-8.47351^{*}$ & -0.01285 & -0.16307 \\
\hline-14 & -0.01152 & $-7.60001^{*}$ & -0.02437 & -0.30934 \\
\hline-13 & -0.0121 & $-7.98263^{*}$ & -0.03647 & -0.46296 \\
\hline-12 & -0.0151 & $-9.95719 *$ & -0.05156 & -0.65459 \\
\hline-11 & -0.00779 & $-5.14098 *$ & -0.05936 & -0.75353 \\
\hline-10 & -0.008 & $-5.27589 *$ & -0.06736 & -0.85506 \\
\hline-9 & -0.01033 & $-6.81083^{*}$ & -0.07768 & -0.98613 \\
\hline-8 & -0.01138 & $-7.50608^{*}$ & -0.08906 & -1.13059 \\
\hline-7 & $4.26 \mathrm{E}-13$ & $2.81 \mathrm{E}-10^{*}$ & -0.08906 & -1.13059 \\
\hline-6 & $-4.3 E-13$ & $-2.82 \mathrm{E}-10^{*}$ & -0.08906 & -1.13059 \\
\hline-5 & -0.01188 & $-7.83862 *$ & -0.10095 & -1.28144 \\
\hline-4 & -0.01638 & $-10.8068^{*}$ & -0.11733 & -1.48942 \\
\hline-3 & -0.0091 & $-6.00579 *$ & -0.12643 & -1.605 \\
\hline-2 & -0.01022 & $-6.73805^{*}$ & -0.13665 & $-1.73468 * * *$ \\
\hline-1 & -0.00903 & $-5.95758 *$ & -0.14568 & $-1.84933 * * *$ \\
\hline (Event Day) 0 & -0.01100 & $-7.25737^{*}$ & -0.15668 & $-1.989 * *$ \\
\hline+1 & -0.01807 & $-11.9200^{*}$ & -0.17475 & $-2.2184^{* *}$ \\
\hline+2 & -0.01244 & $-8.20762 *$ & -0.1872 & $-2.37635^{* *}$ \\
\hline+3 & -0.00386 & $-2.54339 *$ & -0.19105 & $-2.4253^{* *}$ \\
\hline+4 & -0.01242 & $-8.18946 *$ & -0.20347 & $-2.58291^{*}$ \\
\hline+5 & -0.01002 & $-6.61227^{*}$ & -0.21349 & $-2.71016^{*}$ \\
\hline+6 & -0.01053 & $-6.94822 *$ & -0.22403 & $-2.84388^{*}$ \\
\hline+7 & -0.01214 & $-8.00592 *$ & -0.23616 & $-2.99795^{*}$ \\
\hline+8 & -0.01244 & $-8.20595^{*}$ & -0.2486 & $-3.15588^{*}$ \\
\hline+9 & -0.01812 & $-11.9517^{*}$ & -0.26672 & $-3.38589 *$ \\
\hline+10 & -0.01051 & $-6.93118^{*}$ & -0.27723 & $-3.51928^{*}$ \\
\hline+11 & -0.01252 & $-8.25852^{*}$ & -0.28975 & $-3.67821^{*}$ \\
\hline+12 & -0.01506 & $-9.93096 *$ & -0.30481 & $-3.86934^{*}$ \\
\hline+13 & -0.00809 & $-5.3363 *$ & -0.3129 & $-3.97203^{*}$ \\
\hline+14 & -0.14687 & $-6.8811^{*}$ & -0.28975 & $-3.67821^{*}$ \\
\hline+15 & -0.16071 & $-7.2236^{*}$ & $-4.60 \mathrm{E}-01$ & $-5.83651^{*}$ \\
\hline
\end{tabular}

NOTE: Z significance values are 2.57 for $\% 1^{*} ; 1.96$ for $\% 5^{* *} ; 1.645$ for $\% 10^{* * *}$ 
AR, CAR numbers calculated according to the period schedule of this Event study period and their significance are shown in Table 1.

Table 1 shows the abnormal return and cumulative abnormal return values before ( -15 days) and after ( +15 days) the inclusion of companies in Participation 30 Index. When the cumulative abnormal return table values at significance levels of $1 \%, 5 \%$ and $10 \%$ are reviewed, it is seen that two days before the day of the event were significant at the level of $10 \%$, the day of the event and following three days at the level of $5 \%$, and all following days at the level of $1 \%$. As well as all T values were significant, which means that the inclusion of companies in participation index has an effect on stock prices, but t statistical values are negative, which means that this effect is negative. In other words, it can be said that the inclusion of companies in BIST Participation 30 Index adversely affected stock prices. Graph 1 shows that cumulative abnormal returns began to decline before the day of the event and that day and following days decline continued, and the graph is consistent with table values.

Graph 1. Cumulative Abnormal Returns for Before and After [-15+15] Companies' Inclusion in Participation Index

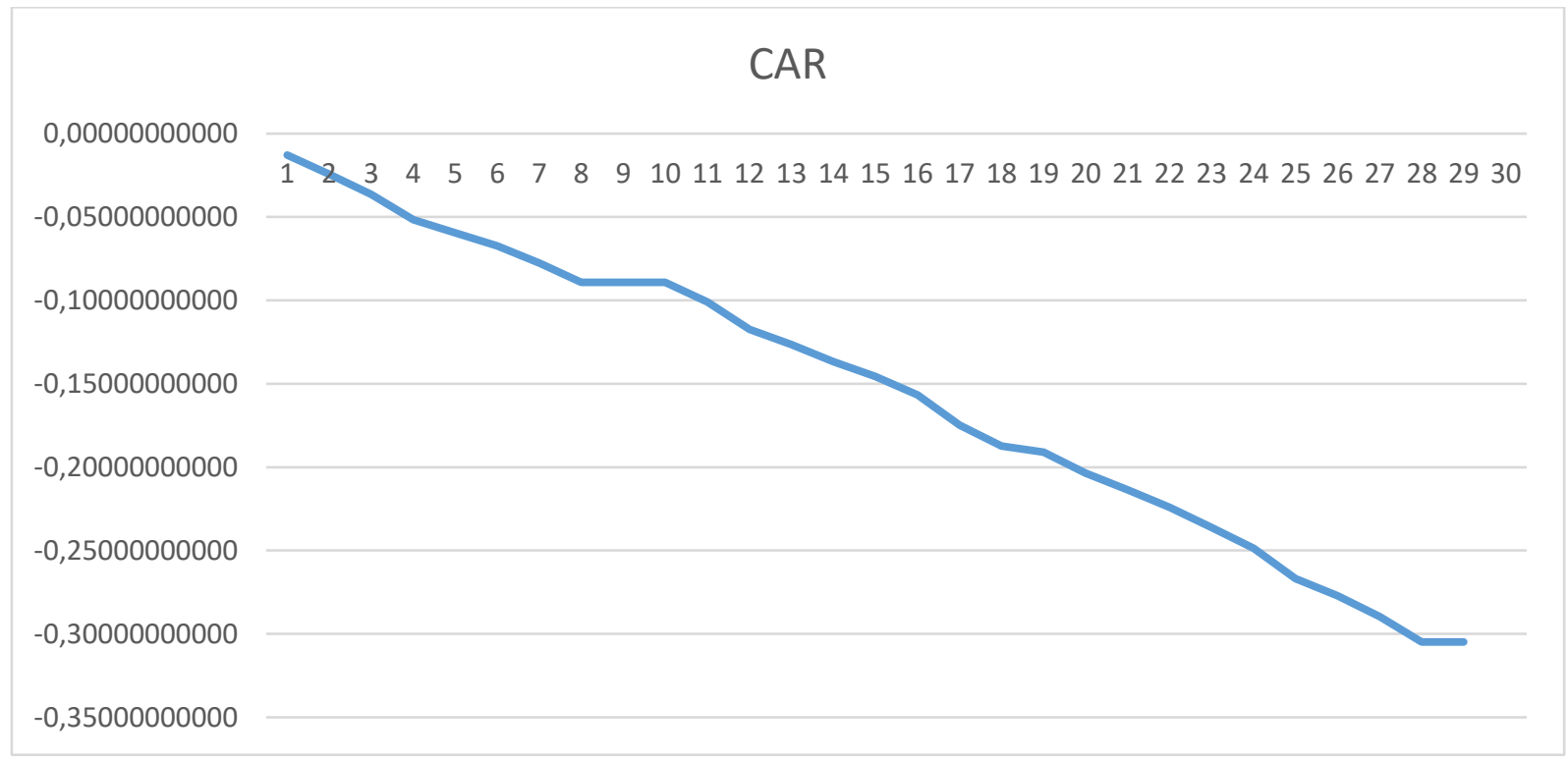

In summary, this result means that the inclusion of companies in BIST Participation 30 Index has a statistically significant but negative effect on the price of stocks. In the studies where the event study method is applied, it is an important problem that the information about the subject go to the market participants in advance and their reflection on the prices beforehand. However, in the days following the day of the event, while the abnormal returns are meaningful, there is only two days meaning before the day of the event.

\section{Conclusion}

Participation indexes constituted from the stocks of companies operating in accordance with Islamic principles have also begun to be calculated in Borsa Istanbul since 2014. With these participation indexes, it is aimed to raise awareness about Islamic banking principles. Thus, it is aimed to provide for the masses that adopt these principles to include the stocks of the companies which are included in participation index, in their portfolios, to expand investor base and increase fund entry in the capital market.

In this study, whether the inclusion of companies operating in Borsa Istanbul in BIST Participation 30 Index has any effect on the financial performance of stocks was investigated with event study method. For this purpose, each date in which the companies were included in the participation index was accepted as the date of the event the cumulative abnormal returns of the stocks were statistically determined and shown on the graph. As a result of the analysis, it was observed that there was a decline on the cumulative abnormal 
returns of stocks before the companies were included in the BIST Participation 30 Index, and the decline continued on the date of the event and following days. The table values shows that a statistically significant but negative results were obtained at $1 \% 5 \%$ and $10 \%$ significance levels, on the date of the event and following days. Accordingly, it can be said that the inclusion of companies in the participation index has a negative effect on the price of the stocks. This result suggests that the investors, who benefits mainly from the fundamental analysis methods in their investment decisions, might show adverse reaction by considering that the financial leverage effect and accordingly profits would decrease in the companies included in the participation index. As it is known, financial leverage is a criterion that shows the effect of any change in operating profit (interest and profit before tax) on earnings per share and this effect is measured by the degree of financial leverage (DFL). Borrowing of interest against loans, interest income (financing expenses) of the operating profit with the reduction of net profit and profit per share, the increase in the operating profit brings a greater increase than the increase of operation profit. Therefore, the financial leverage effect will be at a very low level or not at all in companies with little or no debt $(D F L=1)$. It is considered that the interest rate loans received in the companies that are included in the participation index cannot exceed a certain rate due to the financial criteria and that the investors explain why they may have such a reaction. In addition, the finding of study that the inclusion of the companies in the BIST Participation 30 Index has a statistically significant but negative impact on the stock prices, assuming that securities prices in an advanced capital market reflect all kinds of securities information and hence the invalidity of the Effective Markets Hypothesis that no investor has a chance to beat the market.

The study is expected to contribute to the literature in when considered that studies in the literature focus mainly on the relationship between Islamic and other indexes, or on the comparison of returns performances.

\section{End Notes}

1. In order for the companies to be included in the participation index; the ratio of total interest rate loans to the market value should be less than $30 \%$, the ratio of the interest income to the market value of the marketable securities should be less than $30 \%$ and the ratio of the income from the activity areas specified by the law to total income should be less than $5 \%$.

2. The companies included in the participation 30 index are revised according to the criteria set forth every three months. The Participation 30 index has been included in the analysis since the first date of participation in all of the companies that have been included in the participation index since the publication of the public in 2014. The companies which were closed due to various reasons in 2014-2018 and whose data could not be reached were excluded from the scope of the analysis was carried out on 90 companies using the event study method.

\section{References}

Abbes, M. B. (2012). Risk and return of Islamic and conventional indices. International Journal of Euro-Mediterranean Studies, 5(1), 1-23.

Albaity, M., \& Ahmad, R. (2008). Performance of Syariahand Composite Indices: Evidence from Bursa Malaysia. Asian Academy of Management Journal of Accounting and Finance, 4(1), 23-43.

Al-Khazali, O., Lean H., \& Anis S. (2014). Do Islamic stock indexes outperform conventional stock indexes? A stochastic dominance approach. Pacific-Basin Finance Journal Special Issue on Islamic Banking and Finance, 28, 29-46.

Altın, H., \& Caba, N. (2016). Borsa İstanbul'da işlem gören katılım endekslerinin performanslarının değerlendirilmesi. Finansal Araştırmalar ve Çalışmalar Dergisi, 8(5), 229248.

Atta, H. (2000). Ethical rewards. Published master's thesis, Durham University, UK.

Beik, I. S., \& Wardhana, W. (2011). The relationship between Jakarta Islamic Index and other selected markets: Evidence from impulse response function. Majalah Ekonomi, 21(2), 99-109.

Çıtak, L. \& Ersoy, E.(2016). Firmaların BIST sürdürülebilirlik endeksine alınmasına yatırımcı tepkisi: Olay çalışması ve ortalama testleri ile bir analiz. International Journal of Alanya Faculty of Business, 8(1), 43-57. 
Eyüboğlu, K., \& Bulut, H. (2015). Şirketlere özgü haberlerin hisse performansına etkisi: Bist-30 şirketleri örneği. Karadeniz Teknik Üniversitesi Uluslararası Iktisadi ve Idari Incelemeler Dergisi,8 (16), 113-137.

Gürer, M. (2014). The impact of credit rating changes on the government cost of borrowing in Turkey. A thesis submitted to the graduate, school of social sciences of Middle East Technical University, Ankara.

Hussein, K. \& Omran, M. (2005). Ethical investment revisited: Evidence from Dow Jones Islamic indexes. Journal of Investing, 14(3), 105-124.

Hakim, S., \& Rashidian, M. (2002). Risk and return of Islamic stock market indexes. Presented at the International Seminar of Nonbank Financial Institutions: Islamic Alternatives, Kuala Lumpur, Malaysia.

Hassan, M. K., \& Girard, E. (2010). Faith-based ethical investing: The case of Dow Jones Islamic indexes. Islamic Economic Studies, 17(2), 1-31.

Kılıç, S. (2011), IMKB kurumsal yönetim endeksine dâhil olan şirketlerin getiri performanslarının ölçülmesi. Finans Politik \& Ekonomik Yorumlar, 48 (552), 45-58.

Korkmaz, T., Yaman S., \& Metin S. (2017). Ülke kredi notlarının pay getirileri üzerindeki etkileri: BIST 30 endeksi üzerinde bir event study analizi. Mersin Üniversitesi Sosyal Bilimler Enstitüsü, Sosyal Bilimler Metinleri ICOMEP özel sayısı.

Mackinlay, C. A. (1997). Event studies in economics and finance. Journal of Economic Literature, 35(March 1997), $13-39$.

Mannan, M., \& Credit, S. (2008), Islamic capital markets. Islamic finance: A guide for international business and investment, Consultant Editor: Roderick Millar, Editor: Habiba Anwar, GMB Publishing, United Kingdom and United States of America.

Sakarya, Ş. (2011) iMKB kurumsal yönetim endeksi kapsamındaki şirketlerin kurumsal yönetim derecelendirme notu ve hisse senedi getirileri arasındaki ilişkinin olay çalışması yöntemi ile analizi. Zonguldak Karaelmas Üniversitesi, Sosyal Bilimler Dergisi, 7(13), 147-162.

Savaşan, F., Yardımcıoğlu, F., \& Beşel, F. (2015). The effect of exogenous shocks on participation index of Borsa Istanbul: Permanent or temporary?. International Journal of Islamic Economics and Finance Studies, 1(1), 81-92.

Shubbar, S. A. (2010). Empirical performance of Islamic stock market indices in 2008 credit. Thesis, the University Library, University of Twente.

Sipahi, V. (2010). Kredi derecelendirme duyurularının hisse senedi getirileri üzerindeki etkisi: iMKB banka hisse senetleri üzerinde bir uygulama. Marmara Üniversitesi, Bankacılık ve Sigortacılık Enstitüsü, Sermaye Piyasası ve Borsa ABD, İstanbul.

Yavuz, S., Yıldırım, S., \& Elmas, B. (2015). Kurumsal yönetim endeksi ile şirket hisse senedi getiri ilişkisi: BIST'de bir uygulama. Erzincan Üniversitesi Sosyal Bilimler Enstitüsü Dergisi (ERZSOSDER), 8(2), 73-82.

Yazgan, K. F (2017). Kurumsal yönetim derecelendirmesinin hisse senedi performansına etkisi: BiST kurumsal yönetim endeksi üzerine bir inceleme. Balıkesir Üniversitesi Sosyal Bilimler Enstitüsü, Yüksek Lisans Tezi, Balıkesir.

Yıldırım, H. H. (2017). Kredi derecelendirme kuruluşlarından S\&P, Moody's ve FITCH'in Türkiye için yapmış oldukları not açıklamalarının endeksler üzerine etkisi: Borsa İstanbul Örneği 2012-2016. 2. Lisansüstü İşletme Öğrencileri Sempozyumu, Bursa.

Yıldırım, H. H., Yıldız C., \& Aydemir, Ö. (2018). Kredi derecelendirme kuruluşlarından S\&P, Moody's ve FITCH'in Türkiye için yapmış oldukları not açıklamalarının hisse senedi endeksleri üzerine etkisi: Borsa İstanbul örneği 2012-2016. Balıkesir Üniversitesi, Bankacılık ve Finans Bölümü, Balıkesir.

Yıldız, B. (2015). Katılım 30 endeksi ile BiST 100 endeksinin Performanslarının değerlendirilmesi, TKKB dergisi, 1-15.

Yılmaz, E. D. (2014). Kredi derecelendirme anonslarının ülkelerin kredi temerrüt takas primlerine yansıması: Gelişmekte olan ülkeler üzerine olay analizi. Boğaziçi Üniversitesi Sosyal Bilimler Enstitüsü, Yüksek Lisans Tezi, İstanbul.

www.yahoofinance.com [Access: 20 April 2018]

www.katilimendeksi.org [Access: 20 June 2018] 
This Page Intentionally Left Blank 